\title{
Written Corrective Feedback: What Do Malaysian Learners Prefer And Why?
}

\author{
Mehrdad Rashtchi, Zulqarnain bin Abu Bakar
}

\begin{abstract}
There has been an ongoing debate about the value of providing corrective feedback in writing assignments in English as a foreign/second language classes. Despite the fact, corrective feedback in writing has been analyzed from various perspectives, learners' expectations regarding feedback given by language instructors are still to be considered. This paper investigates the types of written feedback preferred by the Malaysian students. This study investigated how language learners perceive the usefulness of different types and amounts of written corrective feedback, and also the reasons they have for their preferences. Qualitative and quantitative data was collected from 103 ESL students by means of computer generated written questionnaires. The results showed that Malaysian learners react in favor of direct feedback to their written work, and yet they show little tolerance for simply marking the error without explanation. Moreover, considerable number of the respondents favored indirect corrective feedback with a clue. Possible explanations for the results were given with reference to the theoretical constructs of SLA.
\end{abstract}

Keywords: Written corrective feedback, feedback types, learners' preference.

\section{INTRODUCTION}

In the field of SLA (Second Language Acquisition), it is recognized that learning a writing skill is difficult for learners to master. The students' primary motivation for taking writing courses, according to [1], was found to avoid producing errors and to be able to use "perfect" English. In support of the needs of students, teachers in writing classes have employed written corrective feedback. Defined as "responses to learner utterances containing an error" [2]. Many studies have examined the effectiveness of corrective feedback for writing skill.

Inconsistent findings on its effectiveness, however, have been reported [3], [4], [5], [6], [7], [8], [9]. On one hand, a group of researchers [3], [4], [5], [6], [8] argued that corrective feedback might improve writing skills and increase the possibility of improving accuracy over time. On the other hand, [7] pointed out that explicit correction might lead learners to be unnecessarily sensitive to surface/grammar features. They sustained that it is not a specific type of corrective feedback that enhances students' writing skills, but rather it is constant practice that results in improvement over time. Ref. [9] further reached the conclusion that corrective feedback on linguistic errors should not be used excessively.

Revised Version Manuscript Received on April 19, 2019.

Mehrdad Rashtchi, Department of Management and Humanities, Universiti Teknologi PETRONAS, Seri Iskandar, Perak Darul Ridzuan, Malaysia.

Zulqarnain bin Abu Bakar, Department of Management and Humanities, Universiti Teknologi PETRONAS, Seri Iskandar, Perak Darul Ridzuan, Malaysia.
An important area that has attracted much attention recently is how students perceive the usefulness of written corrective feedback. Along with the potential efficacy of corrective feedback in writing, students' attitudes toward error correction has been explored in a number of studies [10], [11], [5], [12], [1], [6].

\section{STATEMENT OF THE PROBLEM}

Despite the support for written corrective feedback in general, the different types and amounts of written corrective feedback that is suitable for different learners are still unclear. Moreover, it has also been suggested that students' preferences play an important role. In other words, students' opinions and preferences for certain amounts and types of written corrective feedback affect their use of it for learning. For example, "if a student prefers one type of written corrective feedback, then he or she may be more likely to pay more attention to the correction and use it for learning than if he or she does not believe in its effects" [13], [14].

Studies on the learners' preferences regarding WCF have found that learners have different attitudes towards WCF. Some studies have found that students prefer to receive large amounts of written corrective feedback regardless of the types of errors on which it is focused [15], [16], [17], [18]. Other studies reveal that "students prefer written corrective feedback in the form of comments on content and ideas rather than on grammatical, structural and surface errors" [19], [20], [21]. Yet, some studies have found that students prefer written corrective feedback in the form of comments on content and ideas as well as explicit written corrective feedback on their structural [22], [1], [23]. Ref. [17] found that students preferred comprehensive written corrective feedback rather than selective written corrective feedback, and that students appreciate explicit correction as well as indirect written corrective feedback such as coding. Therefore, this study examines Malaysian ESL students' preferences and opinions regarding different types and amounts of written corrective feedback, and also explores the reasons why they prefer particular types and amounts of written corrective feedback.

\section{RESEARCH QUESTIONS}

Given the efficacy of the feedback types and the general perception of the feedback types illustrated in the previous section, the present study aims to provide a basis for 
understanding Malaysian ESL students' perception of the feedback types, focusing on the following research questions:

1. What amount of written corrective feedback do Malaysian ESL students think is most useful, and why?

2. What types of written corrective feedback do Malaysian ESL students think are most useful, and why?

\section{PURPOSE OF THE STUDY}

As mentioned earlier the aim of this study is to examine Malaysian ESL students' opinions and preferences for different types and amounts of written corrective feedback. The current study also explores the reasons why Malaysian ESL students prefer particular types and amounts of written corrective feedback.

\section{V.RESEARCH METHODS}

A questionnaire, which was administered using Google Forms to elicit the learners' opinions about the usefulness of different types and amounts of written corrective feedback, was used to collect quantitative as well as qualitative data. Quantitative data was collected through close-ended questionnaire items with Likert scale formats. Qualitative data was also collected through open-ended questions to gain more in-depth information about why students preferred a particular type or amount of feedback. The open-ended questions allowed participants to describe the reasons they had for their preferred feedback choices.

\section{A. Participants}

This study involved 103 participants from foundation program students in Universiti Teknologi PETRONAS. As it is specified by the university, both groups "attend English writing courses for 3 hours per week. The course mainly concentrates on writing skills including the ability to develop the various ideas but the classes also include work on the formal aspects of language including grammar. These students have successfully completed their SPM, O-Level or equivalent. Generally, this program is to prepare them for admission into UTP degree programs. As an entry requirement to this program, students should pass SPM/ SPMV (or O-level equivalent) with grade $\mathrm{C}$ in some subjects including English language". Therefore, students were proficient enough in reading and writing English to understand the questionnaire items and to provide reliable responses.

\section{B. Instrument}

Data was collected using a survey questionnaire. All of the questionnaire items were based on items from questionnaires used in previous studies that examined similar research questions [16], [1], [24] which increased the validity of the research tool. The quantitative data was collected through close-ended questions and the qualitative data was collected through open-ended questions.

Before the questionnaire was administered in the main study, a pilot study was conducted to find any possible problematic items, and to estimate the time required to complete the questionnaire. None of the data collected in the pilot study was used in this study. The main study was conducted over a one-week period in February 2017. Students were given unlimited time, but none took more than twenty-five minutes to complete the questionnaire.

\section{Data Analysis}

The questionnaire responses were recorded then imported to SPSS 23.0 for statistical analysis. For the quantitative data, the frequencies of responses were calculated. For the questionnaire items that included Likert scales, the means of participants' responses were calculated. Qualitative analysis was conducted on the participants' explanatory responses. To this end, the participants' explanations to the open-ended questions were summarized and categorized according to common themes.

\section{FINDINGS}

The questionnaire results are presented in two main sections: Amounts of written corrective feedback, and Types of written corrective feedback. Participants' responses are presented as well as their explanations for their responses. The explanations are categorized to aid interpretation. The results are discussed in relation to the research questions of this study.

In the first item, participants were asked whether they think that teachers should mark all errors, just some, or none at all and respond only to the ideas and content. On this item, participants were able to choose more than one option. As Table 1 shows, the option "Mark all errors" was the most popular choice for students $(79.6 \%)$. The second most popular option was mark only the errors that interfere with communicating your ideas $(25.2 \%)$.

Table I. Participants' Responses to Different Amounts of Written Corrective Feedback

\begin{tabular}{|l|c|c|}
\hline Options & N & Percent \\
\hline A) Teacher should mark all errors. & 82 & 79.6 \\
\hline $\begin{array}{l}\text { B) Teacher should mark all major errors but } \\
\text { not the minor ones. }\end{array}$ & 19 & 18.4 \\
\hline $\begin{array}{l}\text { C) Teacher should mark most of the major } \\
\text { errors, but not necessarily all of them. }\end{array}$ & 15 & 16.4 \\
\hline $\begin{array}{l}\text { D) Teacher should mark only a few of the } \\
\text { major errors. }\end{array}$ & 4 & 3.9 \\
\hline $\begin{array}{l}\text { E) Teacher should mark only the errors that } \\
\text { interfere with communicating your ideas. }\end{array}$ & 26 & 25.2 \\
\hline $\begin{array}{l}\text { F) Teacher should mark no errors and } \\
\text { respond only to the ideas and content. }\end{array}$ & 5 & 4.9 \\
\hline Total & $\mathbf{1 0 3}$ & $\mathbf{1 4 8 . 4}$ \\
\hline
\end{tabular}

*Participants were allowed to choose as many options as they like. Therefore, total responses add to more than $100 \%$.

Table 2 shows the teachers' and students' explanations for their preferences. Of the 94 students who provided explanations to the above item $(33 \%)$ placed value on the importance of identifying their errors. Some of the learners (23.41\%) explained "it is important for them to know their mistakes in order to improve their writing." 
Table II. Explanations for Different Amounts of Written Corrective Feedback

\begin{tabular}{|c|c|c|c|}
\hline Explanations & $\mathbf{N}$ & Percent & Category \\
\hline $\begin{array}{l}\text { a) It is important for } \\
\text { students to know/identify } \\
\text { their weakness/mistakes. }\end{array}$ & 31 & $33 \%$ & \multirow{2}{*}{$\begin{array}{l}\text { Students' } \\
\text { Concerns }\end{array}$} \\
\hline $\begin{array}{l}\text { b) It is important for } \\
\text { students to improve their } \\
\text { writing. }\end{array}$ & 22 & $23.41 \%$ & \\
\hline $\begin{array}{l}\text { c) Students expect not to } \\
\text { repeat their mistakes in } \\
\text { future. }\end{array}$ & 5 & $5.31 \%$ & \multirow{3}{*}{$\begin{array}{l}\text { Students' } \\
\text { Expectation } \\
\text { s }\end{array}$} \\
\hline $\begin{array}{l}\text { d) Students expect to have } \\
\text { the chance to correct } \\
\text { themselves. }\end{array}$ & 9 & $9.57 \%$ & \\
\hline $\begin{array}{l}\text { e) Students expect to learn } \\
\text { from their mistakes. }\end{array}$ & 12 & $12.76 \%$ & \\
\hline $\begin{array}{l}\text { f) Teacher should point out } \\
\text { all the errors }\end{array}$ & 6 & $6.38 \%$ & \multirow{2}{*}{$\begin{array}{l}\text { Teacher } \\
\text { Responsibil } \\
\text { ity }\end{array}$} \\
\hline $\begin{array}{l}\text { g) Teacher should provide } \\
\text { explanation. }\end{array}$ & 9 & $9.57 \%$ & \\
\hline Total Responses & 94 & $100 \%$ & \\
\hline
\end{tabular}

The rest of the items in the questionnaire examined participants' opinions of the usefulness of different types of written corrective feedback. The types of written corrective feedback were represented by an example of each and participants rated them $(1=$ not useful at all, $2=$ not useful, $3=$ doesn't matter, $4=$ quite useful, and $5=$ very useful). Table 3 shows students' mean ratings for each type of written corrective feedback as well as the percentage of response frequencies derived from 103 responses.

Table III. Descriptive Statistics for Each Feedback

\begin{tabular}{|c|c|c|c|c|c|c|}
\hline \multicolumn{7}{|c|}{ Туре } \\
\hline $\begin{array}{c}\text { Item } \\
\text { Feedbac } \\
\text { k Type }\end{array}$ & $\begin{array}{c}1=\text { not } \\
\text { useful at } \\
\text { all } \\
\text { (Useless) }\end{array}$ & $\begin{array}{c}2= \\
\text { not } \\
\text { usefu } \\
1\end{array}$ & $\begin{array}{c}3= \\
\text { doesn't } \\
\text { matter }\end{array}$ & $\begin{array}{c}4= \\
\text { quite } \\
\text { useful }\end{array}$ & $\begin{array}{c}5= \\
\text { very } \\
\text { usefu } \\
1\end{array}$ & $\begin{array}{c}\text { Mea } \\
\text { n }\end{array}$ \\
\hline A & $6.8 \%$ & $\begin{array}{c}22.3 \\
\%\end{array}$ & $14.6 \%$ & $\begin{array}{c}30.1 \\
\%\end{array}$ & $\begin{array}{c}26.2 \\
\%\end{array}$ & 3.47 \\
\hline B & $2.9 \%$ & $\begin{array}{c}4.9 \\
\%\end{array}$ & $10.7 \%$ & $\begin{array}{c}23.3 \\
\%\end{array}$ & $\begin{array}{c}58.3 \\
\%\end{array}$ & 4.29 \\
\hline C & $28.2 \%$ & $\begin{array}{c}30.1 \\
\%\end{array}$ & $23.3 \%$ & $\begin{array}{c}16.5 \\
\%\end{array}$ & $\begin{array}{c}1.9 \\
\%\end{array}$ & 2.34 \\
\hline D & $10.7 \%$ & $\begin{array}{c}19.4 \\
\%\end{array}$ & $37.9 \%$ & $\begin{array}{c}28.2 \\
\%\end{array}$ & $\begin{array}{c}3.9 \\
\%\end{array}$ & 2.95 \\
\hline E & $2.9 \%$ & $\begin{array}{c}4.9 \\
\%\end{array}$ & $20.4 \%$ & $\begin{array}{c}43.7 \\
\%\end{array}$ & 28.2 & 3.89 \\
\hline
\end{tabular}

$* \mathrm{~A}=$ Clues or directions on how to fix an error. $\mathrm{B}=$ Error correction with a comment. C= Error Identification. $\mathrm{D}=$ Comment with no correction. $\mathrm{E}=$ Correction with no comment.

For clues or directions on how to fix an error (e.g., direction to a certain section of a grammar book, dictionary, or class worksheet), the mean response from students (3.47) demonstrate an overall neutral to positive rating. For error correction with a comment, the mean responses from students (4.29) demonstrate overall positive rating. For error identification, the mean responses from students (2.34) demonstrate an overall negative rating. For comment with no correction, the mean response from students demonstrates an overall neutral (2.95) rating and also for correction with no comment, the mean responses from students (3.89) demonstrate overall positive rating.

Tables 4 to 8 show participants' explanations for the above feedback types. Of the 70 students who provided explanations to their rating for "clues or directions on how to fix an error", almost half of the learners (41.42\%) believe that this type of feedback "is useful yet students need more explanation." However, a number of students also demonstrated that they believe that this type of feedback cannot be very useful as "it is not practical for lazy students" or "it is an extra burden for the student".

Table IV. Explanations for Clues or Directions on How to Fix an Error

\begin{tabular}{|l|c|c|}
\hline Explanations & N & Percent \\
\hline a) It is not practical for lazy students. & 19 & $27.14 \%$ \\
\hline $\begin{array}{l}\text { b) Students will understand the mistake } \\
\text { better. }\end{array}$ & 12 & $17.14 \%$ \\
\hline $\begin{array}{l}\text { c) It is useful yet students need more } \\
\text { explanation }\end{array}$ & 29 & $41.42 \%$ \\
\hline d) It is an extra burden for the student & 10 & $14.30 \%$ \\
\hline Total Responses & $\mathbf{7 0}$ & $\mathbf{1 0 0 \%}$ \\
\hline
\end{tabular}

As it is shown in Table 5, of the 68 students who provided explanations to their rating for "Error Correction with a Comment", the explanations showed that students regard this type of written corrective feedback useful. They believe that this type of feedback "helps students a lot because it provides them with the correct answer directly" (41.18\%), and that "they can remember their mistakes easily" (23.53).

Table V. Explanations for Error Correction with a Comment

\begin{tabular}{|l|c|c|}
\hline Explanations & $\mathbf{N}$ & Percent \\
\hline $\begin{array}{l}\text { a) It helps students a lot because it } \\
\text { provides them with the correct answer } \\
\text { directly. }\end{array}$ & 28 & $41.18 \%$ \\
\hline $\begin{array}{l}\text { b) They can remember their mistakes } \\
\text { easily. }\end{array}$ & 16 & $23.53 \%$ \\
\hline $\begin{array}{l}\text { c) They can use the exam paper as study } \\
\text { source. }\end{array}$ & 3 & $4.41 \%$ \\
\hline $\begin{array}{l}\text { d) They can learn better with this type of } \\
\text { correction. }\end{array}$ & 13 & $19.11 \%$ \\
\hline e) It is easy to understand & 8 & $11.77 \%$ \\
\hline Total Responses & $\mathbf{6 8}$ & $\mathbf{1 0 0 \%}$ \\
\hline
\end{tabular}

According to Table 6 , of the 82 students who provided explanations to their rating for "Error Identification", almost the considerable majority have negative attitudes towards this type of written corrective feedback. This is demonstrated by students' explanations such as "it is not practical" (39.01\%), or "It is confusing" $(46.35 \%)$. However, a small minority (2.44\%) believed that "It can make students look for the correct answer themselves" placing value on student autonomy. 
Table VI. Explanations for Error Identification

\begin{tabular}{|l|c|c|}
\hline Explanations & N & Percent \\
\hline a) It is not practical. & 32 & $39.01 \%$ \\
\hline b) It is confusing. & 38 & $46.35 \%$ \\
\hline $\begin{array}{l}\text { c) Students believe they will repeat the } \\
\text { same mistake. }\end{array}$ & 10 & $12.2 \%$ \\
\hline $\begin{array}{l}\text { d) It can make students look for the } \\
\text { correct answer themselves. }\end{array}$ & 2 & $2.44 \%$ \\
\hline Total Responses & $\mathbf{8 2}$ & $\mathbf{1 0 0 \%}$ \\
\hline
\end{tabular}

For "Comment with no Correction", students' explanations were various. Some considered this feedback as a useful one and believed that "it is useful for some students who like some challenge" (10.52\%) and that "it might be effective" $(30.27 \%)$. However, other students didn't seem to be so sure about the usefulness of this type of feedback. They believed that "It is not very clear" $(25 \%)$, or "students might repeat the same mistake" (21.06\%).

\section{Table VII. Explanations for Comment with no} Correction

\begin{tabular}{|l|c|c|}
\hline Explanations & N & Percent \\
\hline a) Students might repeat the same mistake. & 16 & $21.06 \%$ \\
\hline $\begin{array}{l}\text { b) It might be effective but it is better to } \\
\text { provide students with correct form. }\end{array}$ & 23 & $30.27 \%$ \\
\hline $\begin{array}{l}\text { c) It is useful for some students who like } \\
\text { some challenge. }\end{array}$ & 8 & $10.52 \%$ \\
\hline d) It is not very clear. & 19 & $25 \%$ \\
\hline $\begin{array}{l}\text { e) Students may have the chance to correct } \\
\text { the mistake themselves. }\end{array}$ & 10 & $13.15 \%$ \\
\hline Total Responses & $\mathbf{7 6}$ & $\mathbf{1 0 0 \%}$ \\
\hline
\end{tabular}

It seems that "Correction with no Comment" is generally popular among the Malaysian students. Of the 69 students who provided explanations to their rating for "Correction with no Comment", half of the students believe that this type of feedback is "is easy to follow" $(52.2 \%)$. Meanwhile, fewer students seem to cast doubt on its usefulness and refer to the disadvantages of this type of feedback. They believed that "students will not know why their answer is wrong" (4.30\%) or "students might repeat the same mistake in a slightly different situation" $(1.45 \%)$

Table VIII. Explanations for Correction with no Comment

\begin{tabular}{|l|c|c|}
\hline Explanations & N & Percent \\
\hline a) It perfectly points out the error. & 28 & $40.6 \%$ \\
\hline b) It is easy to follow. & 36 & $52.2 \%$ \\
\hline $\begin{array}{l}\text { c) Students will not know why their answer } \\
\text { is wrong. }\end{array}$ & 3 & $4.30 \%$ \\
\hline $\begin{array}{l}\text { d) Students might repeat the same mistake } \\
\text { in a slightly different situation. }\end{array}$ & 1 & $1.45 \%$ \\
\hline e) It needs explanation. & 1 & $1.45 \%$ \\
\hline Total Responses & $\mathbf{6 9}$ & $\mathbf{1 0 0 \%}$ \\
\hline
\end{tabular}

With respect to the research questions posed in this study, the results of this research are discussed in the following. The first research question asked what amount of written corrective feedback Malaysian learners think is most useful, and why. The results of this research found that students

thought it most useful for teachers to provide written corrective feedback on as many errors as possible and showed preference for larger quantities of error correction. Students believed that if the teacher marks only a few errors or mark no errors and respond only to ideas and content would not be beneficial. Thus, to students, the larger the quantity of written corrective feedback, the more useful they think it is. When they were asked for their explanations, students were rather consistent, believing that seeing their errors marked will help them learn and remember them better than if their errors are not marked.

The second research question asked what types of written corrective feedback students think are most useful, and why. The students showed approval of having their errors explicitly marked and corrected with written corrective feedback such as error correction with a comment and error correction with no comment. Their explanation was that explicit types of written corrective feedback allow them to remember their errors and understand how to fix them. Most students explained that a clue with no correction is not useful because students need more specific advice. This preference suggests that students prefer explicit and explanatory written corrective feedback rather than being left to self-correct, despite the fact that self-correction has been found to be useful in some previous research [4], [25], [26]

\section{CONCLUSION}

The current study attempted to report the preferences of the five written corrective feedback types of Malaysian ESL learners as well as the amount of the feedback they believe is useful. The results of this study show that Malaysian ESL learners react in favor of direct approaches of corrective feedback in their written work, and yet they show little tolerance for indirect feedback or simply marking the error without an explanation. Also, the findings suggest that students do not place high value on learner autonomy when it comes to the amount of the feedback they want to receive and students thought it most useful for teachers to provide written corrective feedback on as many errors as possible.

It is interesting in light of the findings in the study the preference of the Malaysian learners do not match with the efficient feedback types pointed out by previous studies. According to a number of studies, which created controversial debate over the effectiveness of corrective feedback, direct and explicit feedback, which was the most favored written corrective feedback type among Malaysian learners, is considered a less beneficial form of written corrective feedback. Ref. [3], [4], [5], [6], [8] pointed out that students that received indirect corrective feedback generally outperformed those that received direct corrective feedback. It can be concluded that an efficient type of corrective feedback and learners' preference are in conflict. Therefore, the English teachers' responsibility, it would seem, is to usefully combine the two complementary feedback types to provide proper comments, thereby aiding learners in developing English writing skills. 


\section{REFERENCES}

1. Leki, I. (1991). The preferences of ESL students for error correction in college-level writing classes. Foreign Language Annals, 24(3), 203-218.

2. Ellis, R. (2008). The study of second language acquisition (2nd ed.). Oxford: Oxford University Press. Ellis, R. (2008). A typology of written corrective feedback types ELT Journal, 63(2), 97-107.

3. Cho, M-H., \& Lee, J-W. (2015). Effects of feedback types on college students' English writing performance. English Language \& Literature Teaching, 21(2), 175-195.

4. Ferris, D., \& Roberts, B. (2001). Error feedback in L2 writing classes how explicit does it need to be? Journal of Second Language Writing, 10, 161-84.

5. Ji, X. (2015). Error correction in college EFL writing instruction: Students' expectations and correction effects. The Journal of Asia TEFL, 12(1), 117-140.

6. Liu, Y. (2008). The effects of error feedback in second language writing. Arizona Working Papers in SLA \& Teaching, 15, 65-75.

7. Robb, T., Steven R., \& Shortreed, I. (1986). Salience of feedback on error and its effect on EFL writing quality. TESOL Quarterly, 20, 83-95.

8. Sampson, A. (2012). Coded and uncoded error feedback: Effects on error frequencies in adult Colombian EFL learners' writing. System, 40, 494-504.

9. Truscott, J. (2007). The effect of error correction on learners ability to write accurately. Journal of Second Language Writing, $16,255-72$.

10. Chin, C. (2007). EFL learners' perceptions on English writing tasks and teacher feedback. English Language \& Literature Teaching, 13(1), 1-26.

11. Ishii, Y. (2011). A survey of learners' preferences about teacher's feedback on writing. Proceedings of the PAAL. China, 16, 403-409.

12. Kim, D. B. (2005). Writing feedback: Assessing Korean learners' viewpoints and strategies for dealing with them. English Language Education, 31, 7-18.

13. McCargar, D. (1993). Teacher and student role expectations: Cross-cultural differences and implications. The Modern Language Journal, 77,192-207.

14. Schulz, R. A. (1996). Focus on form in the foreign language classroom: Students' and teachers' views on error correction and the role of grammar. Foreign Language Annals, 29, 343-364.

15. Cathcart, R. L., \& Olsen, J. E. W. B. (1976). Teachers' and students' preferences for error correction of classroom conversation errors. In J. F. Fanselow and R. H. Crymes (Eds.) On TESOL '76: Selections based on teaching done at the 10th annual TESOL convention (pp. 41-53). Washington: TESOL.

16. Ferris, D. (1997). The influence of teacher commentary on student revision. TESOL Quarterly, 31, 315-339.

17. Lee, I. (2005). Error correction in the L2 classroom: What do students think? TESL Canada Journal, 22, 1-16.

18. Radecki, P. M., \& Swales, J. M. (1988). ESL student reaction to written comments on their written work. System, 16, 355-365.

19. Semke, H. D. (1984). Effects of the red pen. Foreign Language Annals, 17(3), 195-202.

20. Zamel, V. (1985). Responding to student writing. TESOL Quarterly, 19, 79-101.

21. Woroniecka, I. (1998). A nonnative student's reactions to instructors' feedback on his papers: A case study of an undergraduate history student(Master's thesis). University of Toronto: Department of Curriculum, Teaching, and Learning: Ontario Institute for Studies in Education of the University of Toronto.

22. Ashwell, T. (2000). Patterns of teacher response to student writing in a multiple-draft composition classroom: Is content feedback followed by form feedback the best method? Journal of Second Language Writing, 9, 227-257.

23. Ziv, N. D. (1984). The effect of teacher comments on the writing of four college freshmen. In R. Bach and L. S. Bridwell (Eds.), New directions in composition research (pp. 362-280). New York: Guilford Press.

24. Saito, H. (1994). Teachers' practices and students' preferences for feedback on second language writing: A case study of adult ESL learners. TESL Canada Journal, 11(2), 46-70.

25. Hendrickson, J. M. (1977). Error analysis and selective correction in the adult ESL classroom: An experiment. ERIC
Document Reproduction Services, ED 135260

26. Makino, T. Y. (1993). Learner self-correction in EFL written compositions. ELT Journal, 47, 337-341.

\section{AUTHORS PROFILE}

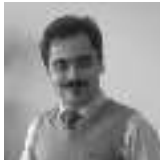

Mehrdad Rashtchi is a PhD student in the Management and Humanities Department at Universiti Teknologi Petronas. He holds an M.A in TESL from Universiti Teknologi Malaysia (UTM) that investigated intercultural competence in EFL classrooms and a B.A in English Language and Literature from Urmia University, Iran. His doctora research investigates the relationship between English language learners' preference for different types of written corrective feedback and their multiple intelligences profile.

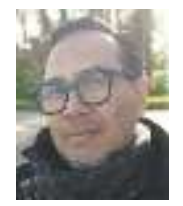

Zulqarnain Abu Bakar holds a PhD in Linguistics, M.A in Applied Linguistics and a B.A in English Literature. With more than 30 years of teaching experience, he has taught English and English Linguistics at various levels. His research interests include, Language and Communication, Phonetics and Phonology, Error Corrections, Error in Pronunciation and Applied Linguistics. He is currently an academic staff member at the Department of Management \& Humanities, Universiti Teknologi Petronas. 